\title{
Etic or Emic? Measuring Culture in International Business Research
}

\author{
Lung-Tan Lu \\ Associate Professor, Department of Management, Fo Guang University \\ 160 Linwei Rd., Juaushi Shiang, Yilan 262, Taiwan \\ Tel: 886-3-987-1000 ext. 23812 E-mail: 1tlu@mail.fgu.edu.tw
}

$\begin{array}{ll}\text { Received: February 18, } 2012 & \text { Accepted: March 19, } 2012 \quad \text { Published: May 1, } 2012 \\ \text { doi:10.5539/ibr.v5n5p109 } & \text { URL: http://dx.doi.org/10.5539/ibr.v5n5p109 }\end{array}$

\begin{abstract}
How to measure culture has been a fundamental challenge for scholars in the field of international business. Approaches, as well as contexts relating to culture, national culture, and dimensional culture, are their major concerns. It is suggested that etic categories may be useful for comparative analysis, but need corroboration from fieldwork and must be open to new elements collected by an emic approach. Moreover, international business research with cultural issues would benefit from combining the etic and emic approaches.
\end{abstract}

Keywords: Culture, Measurement, International business, Methodology

\section{Etic and Emic Approaches}

Two main approaches are frequently discussed in cross-cultural literature: etic and emic (House et al., 2004: 19). The distinction between the emic and etic approaches was initially proposed by Pike (1954) and adapted to develop typologies for cross-cultural comparison derived from field data (Sanday, 1979). Etic and emic researchers have quite diverse assumptions about culture based on their own constructs. Etic researchers tend to segregate common components of culture and test hypotheses. The etic approach attempts to identify universal aspects of human behavior and seeks to find universal processes that transcend cultural differences or to produce new theories that can be utilized across cultures (Fukuyama, 1990; Ridley et al., 1994). In other words, this approach assumes that all cultures can be compared in terms of generalizable phenomena. In contrast, the emic approach attempts to identify culture-specific aspects of concepts and behavior, which cannot be comparable across all cultures. Emic researchers assume that the best way to understand a culture as an integrated system. The endeavor of cultural anthropologists to understand culture from "the native's point of view" was the main foundation of the emic approach (Malinowski, 1922). In the field of cross-cultural research, the emic approach involves examining one culture at a time to evaluate how insiders or participants interpret a phenomenon. The criteria for evaluating behaviors relate to the insiders, and the structure is discovered by the researchers. On the other hand, the etic approach involves comparing different cultures. Behavior is studied from the perspective of an outsider, the criteria for evaluating behaviors are viewed as "universal" and the structure is created by the researchers.

Hofstede's dimensional culture is one of the most utilized constructs in cultural event research and is based upon the results of questionnaire surveys. However, this approach does not include issues of ethnicity and multi-culturalism. Multi-culturalism is often related to ethnic differentiations within societies or countries. For instance, in a multi-cultural country, such as the People's Republic of China (PRC), Chinese culture is often viewed as the culture of the Han people. Cultural event research offers little explanation for such inquiries as "What are Chinese values?" or "Why and how did these values emerge in this place?" More important to international business research is how these values affect people doing business. Hence, it is not surprising that researchers in the field of international business have faced inconclusive results (Robson et al., 2002).

\section{Culture and National Culture}

How to measure culture has been a fundamental challenge for scholars in the field of international business and still is in debate (Gould \& Grein, 2009; Venaik \& Brewer, 2010; Leung et al., 2011). It is necessary to understand the concept of culture in order to discuss the relationship between culture and international business. Anthropologists have defined culture in many ways. There were more than 160 definitions of culture in the 1960's (Kroeber \& Kluckhohn, 1963). The phenomenon of numerous definitions implies that every scholar may view culture from different angles. In other words, different elements are collected when the concepts of culture are defined. It is hard to say that any single definition can be satisfied, because language has limitations in describing abstract concepts of 
culture. Hereafter, we assume that culture is an aggregate of numerous elements. Therefore, "A" culture and "B" culture in Figure 1 can be presented as follows:

(1) A culture $=\{\mathrm{X} 1+\mathrm{X} 2+\mathrm{X} 3+\ldots \ldots+\mathrm{Xm}\} \quad \mathrm{m} \leqq \mathrm{N}$

(2) $\mathrm{B}$ culture $=\{\mathrm{Y} 1+\mathrm{Y} 2+\mathrm{Y} 3+\ldots \ldots+\mathrm{Ym}\}$

What is the relationship between culture and national culture? Can we say that "A" culture is equal to "A" national culture? Probably not, for instance, Chinese culture cannot be seen as the same as the culture of the PRC. Generally speaking, the concept of "Chinese culture" is viewed as the culture of the Han people. There are fifty-three peoples living in PRC territories, such as the Han, Mongolian, and Tibetan groups. The cultures of these groups are very different from one another. Similar situations can be found in other countries, such as in the United States or Malaysia, where different cultural groups came from other countries with different backgrounds. In United Stated, when Latino, Asian, and African American chat about their ethnic histories together, it would be the European American who feels distanced. Even cultural anthropologists are wondering why their colleagues continue to apply the concept of culture at field works outside the United States, but many citizens in the States cannot speak out an ethnic culture of their own (Tanaka, 2009). In Asia, Malaysia is a country with three main different races: Chinese Indians, and Malays, which have there languages, religions, and cultures. Kennedy (2002) suggested that the GLOBE study misinterpreted the values of Malaysian since the study ignored the cultures and roles of Sino-Malaysian and Indian-Malaysian. Hence, in Figure 1, we draw a circle to represent "A" national culture, a part of which is outside of the "A" culture square. The area that overlaps represents the identical elements within "A" national culture and " $\mathrm{A}$ " culture. The relationship between culture and national culture can be presented as follows:

(3) A culture $=\{\mathrm{X} 1+\mathrm{X} 2+\mathrm{X} 3+\ldots \ldots+\mathrm{Xm}\} \quad \mathrm{m} \leqq \mathrm{N}$

(4) $\mathrm{B}$ culture $=\{\mathrm{Y} 1+\mathrm{Y} 2+\mathrm{Y} 3+\ldots \ldots+\mathrm{Ym}\}$

(5) A national culture $=\{X 1+X 2+X 3+\ldots \ldots+X n\} \quad n \leqq N$

(6) $\mathrm{B}$ national culture $=\{\mathrm{Y} 1+\mathrm{Y} 2+\mathrm{Y} 3+\ldots \ldots+\mathrm{Yn}\} \quad \mathrm{n} \neq \mathrm{m}$

\section{National Culture and Hofstede's Cultural Dimensions}

In this paper, we take the Hofstede's IBM survey, one of the most influential contributions to the field of cross-cultural studies, as an example in explaining the relationship between the etic and the emic approaches. From 1967 to 1973 , the data in the IBM survey were collected through questionnaires that included 160 to 183 standardized items with twenty language versions. The questionnaires were completed by over 117,000 employees of IBM's subsidiaries in seventy-one countries (Hofstede, 2001: 43-46).

Hofstede (1980) analyzed 48 variables (i.e. 48 questions) by using factor analysis and found four factors that can explain $37 \%$ of the variance. Factor 1 included two dimensions: power distance and the reverse of individualism. Uncertainty avoidance and masculinity were Factors 2 and 3. Furthermore, Factor 4 showed a weak and unclear correlation with power distance, which Hofstede called a second power distance factor (Hofstede, 2001: 59).

Hofstede further tried to solve the problems of low factor explanation (37\%) and the correlation between Factors 1 and 4 . He reduced the 48 variables to 32 variables, as the result of which the three different factors explain $49 \%$ of the variance in total (i.e. Factor 1: 24\%, Factor 2: 13\%, and Factor 3: 12\%) (Hofstede, 2001: 58). Items with loading of at least 0.35 for the three factors were included. In this stage, Factor 1 included power distance and individualism dimensions by loading seventeen questions. Factor 2 was masculinity, with thirteen questions. Uncertainty avoidance was the third factor with twelve questions (Hofstede, 2001: 59).

In addition, Hofstede extended his analysis of the four dimensions into a set of fifty-three countries. Power distance (PD) and uncertainty avoidance (UA) were based upon three questions each, and individualism (IDV) and masculinity (MAS) were based upon fourteen questions each. In other words, there were a total of thirty-four questions for the four dimensions, which is far fewer than the original total of 160 to 183 items. 126 to 149 questions were dropped as a result of using an etic approach.

Power Distance (PD) can be defined as the extent to which the less powerful members of institutions and organizations within a country expect and accept that power is distributed unequally. None of the human societies has ever reached absolute equality since some strong forces in our societies maintain existing inequalities. Inequality exist in all human societies, however, some of them are more unequal than others. In organizations, it is related to the degree of hierarchy or level of involvement in decision. Not only is the power distance shown in the ruling members but also in the base of the power hierarchy. Individualism (IDV) refers to the relationship between individuals and the collectivities, which prevails in a given society. On one hand, individuals in these societies can enjoy a large amount of freedom because the binds between people are not tied up. Hence, they tend to take care 
themselves and focus on their own interest. (Hofstede, 1980: 218). For instance, in international business, expatriate managers from high-individualism working in a low-individualism host country may have more conflicts with employees.

Uncertainty avoidance (UA) refers to the degree to which people prefer planned to unstructured situations in their society (Hofstede, 1980). Firms in high UA cultures are characterized by a strong need for rules and regulations; greater structuring of organizational activities; member of staff preference for unambiguous instructions and prejudice toward unexpected ideas and behaviors within companies (Hofstede, 1980). Expatriate managers from low UA cultures would not build bureaucratic structures that make it hard to react to unfolding events. On the other hand, managers from high UA cultures, they may experience stress in dealing with future events with risk. They may take actions to manage with the impact of uncertainty. Masculinity (MAS) relates to the degree to which "masculine" values like boldness, performance and competition triumph over "feminine" values such as quality of life, maintaining warm personal relationships and harmony. In company, it is related to the task-orientation as opposed to the person-orientation of management. Masculine cultures express different roles for men and women. People in such societies have a need to be aggressive. On the other hand, the female cultures stress quality of life and environment over money-oriented life.

Factor analysis functions as a filter, keeping similar elements and eliminating elements that differ. Hofstede filtered "national culture" by using thirty-four questions and obtained four dimensions. Therefore, formulas (5) and (6) can be rewritten as follows:

(7) A national culture $=\{(\underline{P D})+($ IDV $)+(\mathrm{UA})+(\mathrm{MAS})+\mathrm{Xg}+\mathrm{Xh}+\ldots \ldots+\mathrm{Xn}\} \quad \mathrm{n} \leqq \mathrm{N}$

(8) $\mathrm{B}$ national culture $=\{(\underline{\mathrm{PD}})+(\mathrm{IDV})+(\mathrm{UA})+(\mathrm{MAS})+\mathrm{Yg}+\mathrm{Yh}+\ldots \ldots+\mathrm{Yn}\} \quad \mathrm{n} \neq \mathrm{m}$

(i) Similarity (etic)

(ii) Difference (emic)

(9) $\mathrm{PD}=[\mathrm{X} 1 \mathrm{a}+\mathrm{X} 2 \mathrm{a}+\ldots \ldots+\mathrm{X} 3 \mathrm{p}]$

$\mathrm{IDV}=[\mathrm{X} 1 \mathrm{~b}+\mathrm{X} 2 \mathrm{~b}+\ldots \ldots+\mathrm{X} 14 \mathrm{q}]$

$\mathrm{UA}=[\mathrm{X} 1 \mathrm{c}+\mathrm{X} 2 \mathrm{c}+\ldots \ldots+\mathrm{X} 3 \mathrm{r}]$

$\mathrm{MAS}=[\mathrm{X} 1 \mathrm{~d}+\mathrm{X} 2 \mathrm{~d}+\ldots . .+\mathrm{X} 14 \mathrm{~s}] \quad \mathrm{X} 1 \mathrm{a} \neq \mathrm{X} 1 \mathrm{~b} \neq \mathrm{X} 1 \mathrm{c} \neq \mathrm{X} 1 \mathrm{~d}$

Hofstede's four dimensions searched for similarity (etic) among the fifty-three countries. Following Hofstede's IBM survey, the formulas of national culture can be divided into two parts: (1) similarity includes four dimensions and various elements, and (2) difference contains numerous elements. "A" and "B" national cultures can be presented as formulas (7) and (8). In formula (9), each dimension becomes a sub-collection in the national culture.

The etic approach of search for the similar elements among cultures will drop the unique parts of each culture. This is evidenced by Hostede's IBM survey, as discussed above. Also confirming this is that a group of twenty-four scholars, called The Chinese Culture Connection (1987), found a new dimension (i.e. Confucian work dynamism) that was not related to any of Hofstede's four dimensions. This implies that Hofstede's four dimensions are not equal to the similarity of national cultures, but are only part of them.

\section{Hofstede's Four Dimensions and Long-term Orientation}

The questionnaire in the Chinese Culture Connection (1987), or The Chinese Value Survey (CVS), was written in Chinese and used Chinese values, unlike Hofstede's IBM survey, which was developed in English and used Western values. The CVS questionnaire included forty items and was carried out in twenty-two countries. Collaborators were asked to translate the questionnaire from the Chinese or English version into their local language if neither of these was the native language of the respondents. As in Hofstede's IBM survey, the researchers used factor analysis to examine the data and found four factors that can explain $56.9 \%$ of the variance in total (i.e. Factor 1: $21.3 \%$, Factor 2: $15.4 \%$, Factor 3: $11.5 \%$, and Factor 4: $8.7 \%$ ). Items with loading of at least 0.35 for the three factors were included.

CVS Factor 1 (integration) includes eleven questions. Confucian work dynamism is CVS Factor 2 with eight questions, and human-heartedness is the third factor, with five questions. The final CVS factor (moral discipline) included five questions (The Chinese Culture Connection, 1987). Hofstede's PD and IDV dimensions were both correlated significantly with CVS I and CVS IV. Furthermore, Hofstede's MAS dimension was highly correlated with CVS III. CVS II (Confucian work dynamism) was not correlated with any of Hofstede's four dimensions, so it was adopted as the fifth dimension in Hofstede's book (1991). Hofstede and Bond (1988) argue that Confucian work dynamism was found because of the Western mind. However, we would like to provide a different perspective to explain why the fifth dimension was found. 
Figure 3 is developed as a model of three national cultures, and we try to explain the relationship between Hofstede's four dimensions and Long-Term Orientation (LTO). Let us assume that the model of three national cultures is Hofstede's survey (see Figure 3). The central circle represents the four dimensions found through factor analysis. K1-K3 represent factors which can be found by surveys with a smaller number of countries than in Hofstede's survey. M represents a factor outside of Hofstede's four dimensions.

A question arises: Where is the location of the LTO? Is it K1, K2, K3, or M1? Theoretically, the more countries used in the factor loading, the fewer factors we can have. Therefore, it is not surprising that CVS can have a brand-new dimension that is not correlated to any of Hofstede's dimensions. It is quite possible that, if Hofstede only used the same twenty-two countries as in the CVS to conduct his factor analysis, he could have more than four dimensions.

\section{Discussion and Suggestions}

For managers in multinational enterprises, one of the most difficult aspects of doing business in a foreign country is to understand the similarity and differences in cultural insights and values. A difficult issue with any cross-cultural research is to keep a balanced and comparative frame of reference. Cross-cultural studies using an etic approach with quantitative methods have come under growing criticism (Leung \& Ven de Vijver, 1996; Efferin \& Hopper, 2006). First, analyses may be too generalized - they presume a group of people living in a society or country, such as the Chinese, to be relatively homogenous. The researchers pay little attention to cultural diversity in a society or country or to interactions between mainstream and ethnic cultures. Second, such studies tend to be stationary and to disregard cultural change. Third, they assume that the concept of a people (e.g. Chinese) is objective, while it may be subjective in nature. Finally, there is too much dependence upon survey research instruments. Dow and Karunaratna (2006) used the approach of atic to develop and examine a range of potential distance stimuli including differences in culture, language, religion, education, and political systems. However, it is found that the composite measure of Hofstede's cultural dimensions is not significant. It is argued that the original data are over two decades old and specific to a single company. Hofstede's cultural dimensions contributed tremendously to the field of international business research. Since the 1980's, Hofstede's five dimensions have led us to compare the similar elements (etic) of national culture around the world. Perhaps it is time to explore the relationships between different parts of culture (emic) and international business activities. This study examines only Hofstede's work, one of the most cited studies in cross-cultural research. Further research can analyze other large-scale research, such as Inglehart et al. (1998), Schwartz (1995), and the GLOBE (2004) projects in order to examine the generality provided by this study.

"Global mind, local root" has been an aspiration for international managers operating their multinational enterprises around the world. Developing global mind need to understand the similarity of national cultures, so the etic approach would be a proper way to explore the resemblance. On the other hand, growing local root need to be aware of the unique elements of local culture, so that the emic method would be a suitable method to discover the sole part of local culture. Etic approach, which examines common elements of cultures and state hypotheses, may be useful for comparative analysis, but need corroboration from fieldwork and must be open to new elements collected by an emic approach (Bhimani, 1999). Morris et al. (1999) argue that the etic and emic approaches are complementary. Greenfield (1996) suggests that the emic approach serves best in exploratory research, but the etic approach serves best in testing hypotheses. Berry (1990) suggests a three-stage methodology. First, original exploratory research relies on etic concepts and measurement methods from the researcher's home culture. Second stage, researchers may interpret early findings by using emic perspective from other cultures. In the final stage, the researcher tests an explanation constructed from etic approach. It is suggested that researchers should concur neither etic nor emic perspectives are superior and may combine etic and emic approaches in cross-cultural study (Berry, 1969; 1990; Leung et al., 2005; Lu, 2006; Segall et al., 1990). Although there are little study using both methods (e.g. Morris, 1999), we look forward to reading more cross-cultural research combing etic and emic approaches.

\section{Acknowledgments}

This paper was presented at the 2011 Annual Meeting of Academy of International Business, Nagoya, Japan. The author would like to thank Professor Peter J Buckley and the reviewers for their helpful comments on drafts of this paper.

\section{References}

Berry, J. W. (1969). On cross-cultural comparability. International Journal of Psychology, 4(2), 119-238. http://dx.doi.org/10.1080/00207596908247261 
Berry, J. W. (1990). Imposed etics, emics, derived etics: Their conceptual and operational status in cross-cultural psychology. In T. N. Headland, K. L. Pike and M. Harris (Eds.), Emics and etics: The insider/outsider debate (pp. 28-47). CA: Sage.

Bhimani, A. (1999). Mapping methodological frontiers in cross-national management control research. Accounting, Organizations and Society, 24(5), 413-440. http://dx.doi.org/10.1016/S0361-3682(98)00068-3

Chinese Culture Connection. (1987). Chinese values and the search for culture-free dimensions of culture. Journal of Cross-Cultural Psychology, 18(2). 143-146. http://dx.doi.org/10.1177/0022002187018002002

Dow, D., \& Karunaratna, A. (2006). Developing a multidimensional instrument to measure psychic distance stimuli. Journal of International Business Studies, 37(5), 578-602. http://dx.doi.org/10.1057/palgrave.jibs.8400221

Efferin, S., \& Hopper, T. (2006). Management control, culture and ethnicity in a Chinese Indonesian company. Accounting, Organization and Society, 32(3), 223-238. http://dx.doi.org/10.1016/j.aos.2006.03.009

Fukuyama, M. A. (1990). Taking a universal approach to multicultural counseling. Counselor Education and Supervision, 30(1), 6-17. http://dx.doi.org/10.1002/j.1556-6978.1990.tb01174.x

Gould, S. J., \& Grein, A. F. (2009). Think glocally, act glocally: A culture-centric comment on Leung, Bhagat, Buchan, Erez and Gibson (2005). Journal of International Business Studies, 40(2), 237-254. http://dx.doi.org/10.1057/palgrave.jibs.8400410

Greenfield, P. (1996). Culture as process: Empirical methodology for cultural psychology. In J. W. Berry, Y. H. Poortinga and J. Pandey (Eds.), Handbook of cross-cultural psychology, vol. 1: Theory and Method (2nd ed. pp. 301-346). MA: Allyn and Bacon.

Hofstede, G. (1980). Culture's Consequences. London: Sage.

Hofstede, G. (1991). Culture and Organizations: Software of the mind. London: McGraw-Hill.

Hofstede, G. (2001). Culture's Consequences: Comparing values, behaviors, institutions, and organizations across nations (2nd ed.). London: Sage.

Hofstede, G., \& Bond, M. H. (1988). The Confucius connection: From cultural roots to economic growth. Organization Dynamic, 16(4), 4-21. http://dx.doi.org/10.1016/0090-2616(88)90009-5

House, R. J., Hanges, P. J., Javidan, M., Dorfman, P. W., \& Gupta, V. (2004). GLOBE, Cultures, Leadership, and Organizations: Globe Study of 62 Societies. CA: Sage.

Inglehart, R., Basanez, M., \& Moreno, A. (1998). Human values and beliefs: A cross-cultural sourcebook - Political, religious, sexual, and economic norms in 43 societies. Ann Arbor: University of Michigan Press.

Kennedy, J. C. (2002). Leadership in Malaysia: traditional values, international outlook. Academy of Management Executive, 16(3), 15-25. http://dx.doi.org/10.5465/AME.2002.8540292

Kroeber, A. L., \& Kluckhohn, C. (1963). Culture: A Critical Review of Concepts and Definitions. NY: Vintage Books.

Leung, K., Bhagat, R. S., Buchan, N. R., Erez, M., \& Gibson, C. B. (2005). Culture and international business: recent advances and their implications for future research. Journal of International Business Studies, 36(4), 357-378. http://dx.doi.org/10.1057/palgrave.jibs. 8400150

Leung, K., Bhagat, R. S., Buchan, N. R., Erez, M., \& Gibson, C. B. (2011). Beyond national culture and culture-centricism: A reply to Gould and Grein (2009). Journal of International Business Studies, 42(1), 177-181. http://dx.doi.org/10.1057/jibs.2010.38

Leung, K., \& Van de Vijver, F. (1996). Cross-cultural research methodology. In F. T. Ueong and J. T. Austin (Eds.), Psychology research handbook: A guide for graduate students and research assistants (pp. 351-358). CA: Sage.

Lu, L. (2006). The Relationship between Cultural Distance and Performance in International Joint Ventures: A Critique and Ideas for Further Research. International Journal of Management, 23(3), 436-445.

Malinowski, B. (1922). Argonauts of the western Pacific. London: Routledge.

Morris, M., Leung, K., Ames, D., \& Lickel, B. (1999). Views from inside and outside: Integrating emic and etic insights about culture and justice judgment. Academy of Management Review, 24(4), 781-796. http://dx.doi.org/10.2307/259354

Pike, R. (1954). Language in relation to a united theory of the structure of human behavior, Glendale. AZ: Summer Institute of Linguistics. 
Ridley, R. R., Mondoza, D. W., \& Kanitz, B. E. (1994). Multicultural training: Reexamination, operationalization, and integration. The Counseling Psychologist, 22(2), 277-289. http://dx.doi.org/10.1177/0011000094222001

Robson, M. J., Leonidou, L. C., \& Katsikeas, C. S. (2002). Factors influencing international joint venture performance: theoretical perspectives, assessment, and future directions. Management International Review, 42(4), 385-418.

Sanday, P. R. (1979). The ethnographic paradigm(s). Administrative Science Quarterly, 24(4), 527-38. http://dx.doi.org/10.2307/2392359

Schwartz, S. H. (1992). Universals in the content and structure of values: Theory and empirical tests in 20 countries. In M. Zanna (Ed.), Advances in experimental social psychology (Vol. 25, pp. 1-65). NY: Academic Press.

Segall, M. H., Dasen, P. R., Berry, J. W., \& Poortinga, Y. H. (1990). Human Behavior in Global Perspective: An Introduction to Cross-cultural Psychology. New York: Pergamon.

Tanaka, G. (2009). The Elephant in the Living Room That No One Wants to Talk About: Why U.S. Anthropologists Are Unable to Acknowledge the End of Culture: [1]. Anthropology and Education Quarterly, 40(1), 82-95. http://dx.doi.org/10.1111/j.1548-1492.2009.01029.x

Triandis, H. C. (1995). Individualism and collectivism. Oxford: Westview.

Venaik, S., \& Brewer, P. (2010). Avoiding uncertainty in Hofstede and GLOBE. Journal of International Business Studies, 41(8) , 1294-1315. http://dx.doi.org/10.1057/jibs.2009.96
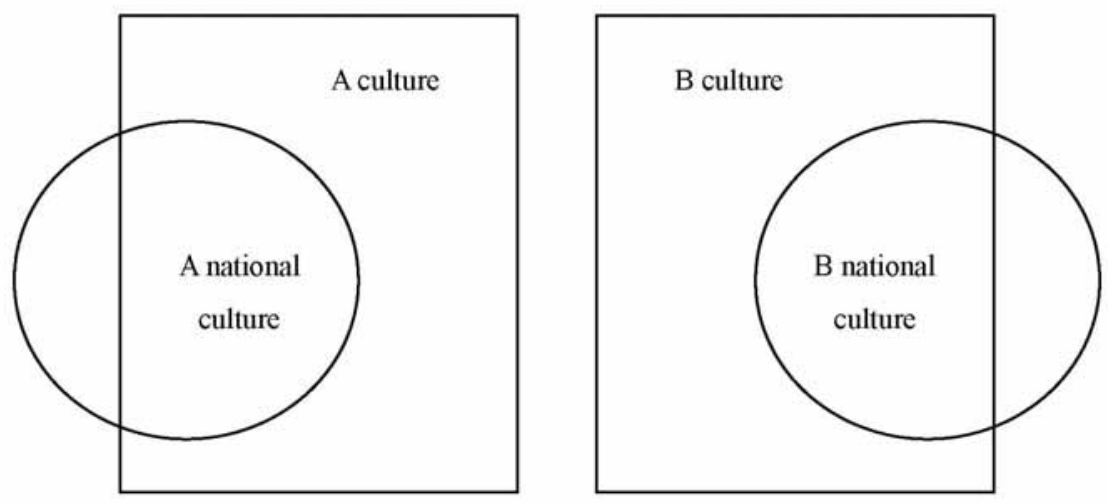

Figure 1. Cultures and national cultures

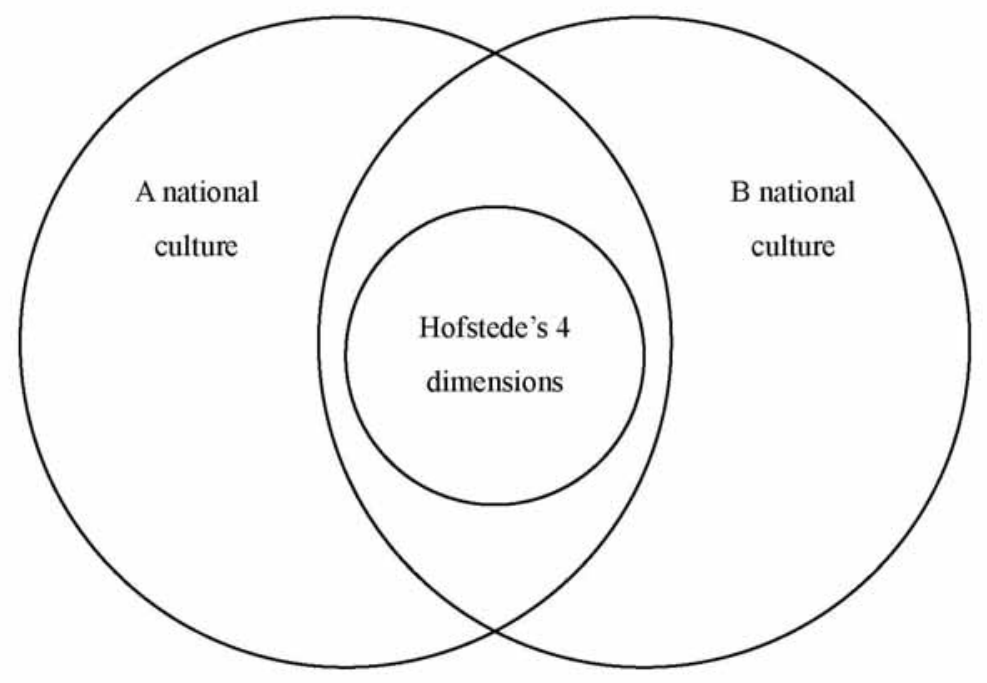

Figure 2. National cultures and Hofstede's four dimensions 


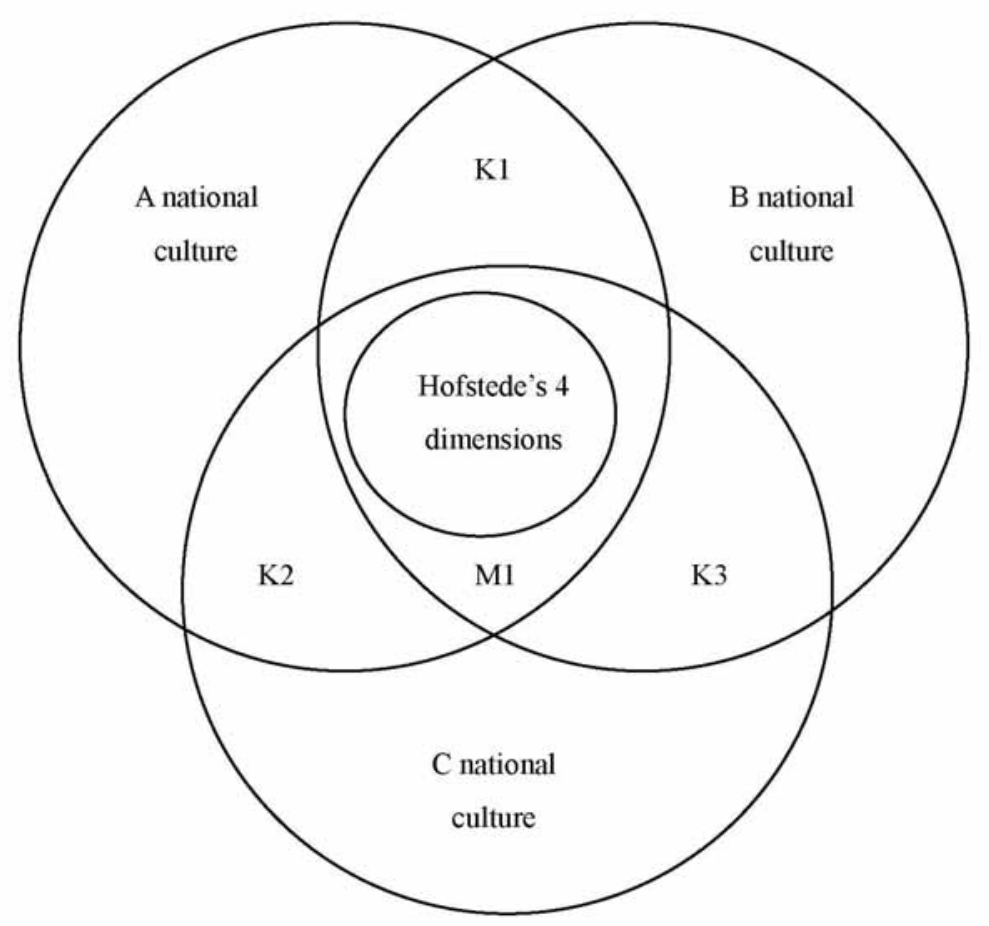

Figure 3. Hofstede's 4 dimensions and long-term orientation 